\title{
The Role of $\boldsymbol{n}$-Valeric Acid in the Synthesis of the Higher Saturated Straight-Ghain Acids Containing an Odd Number of Carbon Atoms in Bovine Milk Fat
}

\author{
BY T. GERSON, J. C. HAWKE AND F. B. SHORLAND \\ Fats Research Laboratory \\ AND W. H. MELHUISH \\ Division of Nuclear Sciences, Department of Scientific and Industrial Research \\ Wellington, New Zealand
}

(Received 11 May 1959)

The synthesis in the udder of the $n$-saturated acids by the successive addition of acetate units has been confirmed by the work of numerous investigators. This subject has been reviewed by Popják (1952), Folley (1952), Glascock (1954), and more recently by Shorland \& Hansen (1957).

The discovery of the saturated straight-chain acids containing an odd number of carbon atoms (' $n$-odd-numbered acids') in the body and milk fats of ruminants (Hansen, Shorland \& Cooke, 1957; Shorland, Gerson \& Hansen, $1955 a, b)$ raises the question of their origin. Some light has been thrown on the mechanism of synthesis of these acids by the work of James, Peeters \& Lauryssens (1956), who found that labelled propionate perfused through a cow's udder gave rise to the higher ' $n$-odd-numbered acids' by chain elongation with acetate. The small amounts of propionate found in the blood by Annison (1954) could therefore be utilized for the formation in vivo of higher ' $n$-oddnumbered acids' present in the milk fats. It could be assumed that valerate is formed by the addition of acetate to propionate as an intermediary in the synthesis of the higher ' $n$-odd-numbered acids'. This is difficult to reconcile with the results of Popják, French, Hunter \& Martin (1951), who

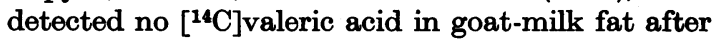
the injection of labelled acetate into the jugular vein, suggesting that the valeric acid present is not formed endogenously but is derived from the rumen. On the other hand, such an origin seems improbable in view of the failure of Annison (1954) to detect valeric acid in sheep's blood.

To explore further the role of valeric acid in fatty acid synthesis we have determined the ${ }^{14} \mathrm{C}$ activity of the constituent fatty acids in butterfat from a cow which had been given an intrajugular injection of sodium [carboxy-14 C]valerate (M. Kleiber, personal communication, 1956).

\section{EXPERIMENTAL}

The dairy cow used in this experiment weighed $449 \mathrm{~kg}$., and produced approximately $10 \mathrm{~kg}$. of milk daily. After milking, sodium [carboxy $\left.-{ }^{14} \mathrm{C}\right]$ valerate $(5 \cdot 0 \mathrm{mc})$ was injected into the jugular vein. The milk yields and activities of the milk fats are shown in Table 1.

Isolation of fatty acids. The butterfat ( $96 \mathrm{~g}$.) was saponified by the method of Henry \& Kon (1942) and the soaps converted into acids with $40 \%$ ( $/ / \mathrm{v}) \mathrm{H}_{2} \mathrm{SO}_{4}(10 \%$ excess), and steam-distilled. The steam-volatile fatty acids were neutralized with $\mathrm{KOH}$, evaporated to dryness and analysed by gas-liquid chromatography (James \& Martin, 1952). The non-volatile fatty acids were extracted with diethyl ether, washed with water until neutral to Congo red and dried in vacuo on a water bath. The acids were then separated into 'solids' and 'liquids' by crystallization three times from $15 \mathrm{vol}$. of acetone at $-38^{\circ}$. The 'solids' and 'liquids' respectively were converted into methyl esters and fractionated in a spiral column (column E; Shorland, 1952), and further resolved into their components by gasliquid chromatography, the purified constituents being collected as described by James et al. (1956). The fatty acid composition was calculated as outlined by Hilditch (1956) after allowance for the $(+)$-anteiso acids. The proportions of the $(+)$-anteiso acids were determined from the optical rotation of the methyl ester fractions (Table 2), by using as the standard the values given by Milburn \& Truter (1954) for the pure substances.

Isolation of glycerol. Glycerol was estimated by the procedure described by Abraham \& Hassid (1957). The fat (approx. 4.0 g.) was saponified (Henry \& Kon, 1942) and the soaps were acidified with $7 \mathrm{ml}$. of $25 \%(\mathrm{v} / \mathrm{v})$ sulphuric acid. The volatile acids were removed by steam distillation for $2 \mathrm{hr}$. The residue was extracted with diethyl ether and the aqueous layer neutralized with aq. $0.5 \mathrm{~N}-\mathrm{KOH}$. The aqueous solution was then evaporated on a water bath and the solid residue dissolved in $20 \mathrm{ml}$. of boiling methanol. On cooling, the precipitate was filtered off and the filtrate evaporated to remove the solvent. The residue was taken up in 2-5 ml. of methanol and again filtered to remove a slight precipitate. Repetition of this last stage resulted in the removal of the remaining salt, and the filtrate was then freed from the solvent on a water bath, the last traces being removed in vacuo.

Determination of specific activities. The samples were adsorbed on carbon-free asbestos and packed into a platinum combustion boat. The combustion was carried out in a semi-micro furnace, with a stream of $\mathrm{CO}_{2}$-free oxygen. The $\mathrm{CO}_{2}$ formed was passed over heated $\mathrm{CuO}$, dried over Anhydrone (British Drug Houses Ltd.) and $\mathrm{P}_{2} \mathrm{O}_{5}$, and collected in traps cooled with liquid oxygen, the surplus 
oxygen being passed out of the system through a soda-lime tube and an $\mathrm{H}_{2} \mathrm{SO}_{4}$ bubbler.

The counting technique used was based on that of Eidinoff (1950). The gas counters were of a conventional type, constructed of Pyrex glass with thin sheet copper sprung against the glass envelope and an anode made of tungsten wire $0.004 \mathrm{in}$. in diameter.

Table 2 shows the reproducibility of the method when tested with radioactive methyl palmitate from the butterfat and with inactive acetic acid.

The specific activities ( $\mu \mathrm{c} / \mathrm{g}$. atom of carbon) of the samples were calculated assuming no end- or wall-effects. However, all determinations are comparable, since they have always been referred to the same counter. The milk-

Table 1. Milk yield and milk-fat radioactivity after the injection of $\left[\right.$ carboxy $\left.-{ }^{14} \mathrm{C}\right]$ valerate

$\begin{array}{cccc}\text { Milk } & \begin{array}{c}\text { Time after } \\ \text { injection } \\ \text { (hr.) }\end{array} & \begin{array}{c}\text { Milk } \\ \text { yield } \\ (\mathrm{kg} .)\end{array} & \begin{array}{c}\text { Activity of } \\ \text { milk fat } \\ (\mu \mathrm{c} / \mathrm{g} . \text { atom }\end{array} \\ \text { 1 } & 3.3 & 1.36 & \text { of } \mathrm{C}) \\ 2^{*} & 10 \cdot 0 & 2 \cdot 45 & 2.95 \\ 3 & 22 \cdot 2 & 4.99 & 6 \cdot 00 \\ & & 1.62\end{array}$

* Saponification equiv., 240.7; iodine val. (Wijs), 35.6. fat sample, which was burned and counted repeatedly in different counters, over a period of approximately one year, gave specific activities constant to within $\pm 1 \%$.

\section{RESULTS AND DISCUSSION}

The fatty acid composition of the milk fat (Table 3) falls within the range normally found (e.g. Hilditch, 1956) but, in addition, some of the minor constituents not usually quantitatively determined have been included. Popják, French, Hunter \& Martin (1951) showed that propionic acid and valeric acid were present in the milk fat of goats, but in the bovine milk fat used in the present investigation these acids were not detected, as in a New Zealand milk-fat sample examined earlier (Hawke, 1957).

The specific activities of $n$-pentadecanoic and $n$-heptadecanoic acids were similar to those of palmitic acid and stearic acid (Table 3). It therefore appears that most of the [carboxy $\left.{ }^{14} \mathrm{C}\right]$ valerate is not utilized directly in the biosynthesis of the ' $n$-odd-numbered acids' by addition of $\mathrm{C}_{2}$, but is degraded to labelled acetate and unlabelled propionate. The labelled acetate would then be used

Table 2. Recovery of carbon dioxide and radioactivity after the combustion and gas counting of labelled methyl palmitate and inactive acetate

\begin{tabular}{|c|c|c|c|c|c|}
\hline \multirow[b]{2}{*}{ Substance } & \multirow{2}{*}{$\begin{array}{l}\text { Wt. } \\
\text { (mg.) }\end{array}$} & \multicolumn{2}{|c|}{ Vol. of $\mathrm{CO}_{2}$ at $23^{\circ}(\mathrm{ml}$.) } & \multirow{2}{*}{\multicolumn{2}{|c|}{$\begin{array}{c}\text { Activity } \\
(\mu \mathrm{c} / \mathrm{g} . \text { of } \mathrm{C})\end{array}$}} \\
\hline & & Found & Calc. & & \\
\hline $\begin{array}{l}\text { Methyl palmitate (labelled) } \\
\text { Methyl palmitate (labelled) } \\
\text { Methyl palmitate (labelled) } \\
\text { Methyl palmitate (labelled) }\end{array}$ & $\begin{array}{r}12 \cdot 8 \\
5 \cdot 1 \\
59 \cdot 2 \\
7 \cdot 0\end{array}$ & $\begin{array}{r}17 \cdot 3 \\
6 \cdot 5 \\
74 \cdot 9 \\
8 \cdot 6\end{array}$ & $\begin{array}{r}18 \cdot 4 \\
7 \cdot 3 \\
85 \cdot 2 \\
10 \cdot 1\end{array}$ & $\left.\begin{array}{l}0 \cdot 410 \\
0 \cdot 411 \\
0 \cdot 409 \\
0 \cdot 395\end{array}\right)$ & $\begin{array}{c}\text { Mean } \pm \text { s.D. } \\
0.406 \pm 0.007\end{array}$ \\
\hline Acetic acid (inactive) & $245 \mu$ equiv. & $12 \cdot 2$ & $12 \cdot 4$ & & - \\
\hline
\end{tabular}

Table 3. Fatty acids of butterfat and their labelling $10 \mathrm{hr}$. after injection of [carboxy- $\left.{ }^{14} \mathrm{C}\right]$ valerate

\begin{tabular}{|c|c|c|c|}
\hline Fatty acid & $\begin{array}{l}\text { Composition } \\
\text { (\%, by wt.) }\end{array}$ & $\begin{array}{c}\mu \mathrm{c} / 100 \mathrm{~g} . \text { of } \\
\text { total fatty acids }\end{array}$ & $\begin{array}{l}\mu \mathrm{C} / \mathrm{g} \text {. atom } \\
\text { of } \mathrm{C}\end{array}$ \\
\hline $\begin{array}{l}\mathrm{C}_{2} \text { saturated } \\
\mathrm{C}_{4} \text { saturated } \\
\mathrm{C}_{6} \text { saturated } \\
\mathrm{C}_{8} \text { saturated } \\
\mathrm{C}_{10} \text { saturated } \\
\mathrm{C}_{10} \text { unsaturated }\end{array}$ & $\begin{array}{l}0 \cdot 12 \\
3 \cdot 11 \\
2 \cdot 08 \\
1 \cdot 03 \\
3 \cdot 13 \\
0 \cdot 08\end{array}$ & $\begin{array}{l}0 \cdot 02 \\
2 \cdot 25 \\
1 \cdot 48 \\
0 \cdot 41 \\
0 \cdot 11 \\
-\end{array}$ & $\begin{array}{r}4 \cdot 32 \\
15 \cdot 96 \\
13 \cdot 80 \\
7 \cdot 20 \\
0 \cdot 60 \\
-\end{array}$ \\
\hline $\begin{array}{l}\mathrm{C}_{12} \text { saturated } \\
\mathrm{C}_{12} \text { unsaturated } \\
\mathrm{C}_{14} \text { saturated } \\
\mathrm{C}_{14} \text { unsaturated } \\
\mathrm{C}_{15} * \text { saturated } \\
\mathrm{C}_{15} \text { anteiso saturated } \\
\mathrm{C}_{18} \text { saturated } \\
\mathrm{C}_{18} \text { unsaturated } \\
\mathrm{C}_{17} \text { * saturated } \\
\mathrm{C}_{17} \text { anteiso saturated } \\
\mathrm{C}_{18} \text { saturated } \\
\mathrm{C}_{18} \text { unsaturated }\end{array}$ & $\begin{array}{r}6 \cdot 03 \\
0 \cdot 39 \\
7 \cdot 69 \\
1 \cdot 04 \\
0 \cdot 80 \\
0 \cdot 36 \\
26 \cdot 91 \\
4 \cdot 94 \\
0 \cdot 80 \\
0 \cdot 41 \\
8 \cdot 38 \\
32 \cdot 70\end{array}$ & $\begin{array}{l}4 \cdot 34 \\
0 \cdot 23 \\
4 \cdot 54 \\
0 \cdot 38 \\
0 \cdot 21 \\
0 \cdot 03 \\
8 \cdot 88 \\
0 \cdot 52 \\
0 \cdot 23 \\
0 \cdot 04 \\
2 \cdot 29 \\
2 \cdot 00\end{array}$ & $\begin{array}{r}12 \cdot 00 \\
9 \cdot 84 \\
9 \cdot 60 \\
5 \cdot 88 \\
4 \cdot 20 \\
1 \cdot 32 \\
5 \cdot 28 \\
1 \cdot 68 \\
4 \cdot 56 \\
1 \cdot 68 \\
4 \cdot 32 \\
0 \cdot 96\end{array}$ \\
\hline $\begin{array}{l}\text { Total } \\
\text { Glycerol }\end{array}$ & $\begin{array}{c}100 \cdot 00 \\
-\end{array}$ & 27.96 & $\overline{15 \cdot 0}$ \\
\hline
\end{tabular}

* The amounts of $n-\mathrm{C}_{15}$ and $n-\mathrm{C}_{17}$ saturated acids have not been determined in the present work. The figure recorded for the $n$ - $\mathrm{C}_{15}$ saturated acid is based on an earlier analysis of New Zealand butterfat by Shorland, Gerson \& Hansen (1955b). From results previously obtained on butterfat (Shorland \& Hansen, 1957) it is estimated that the proportion of $n$ - $\mathrm{C}_{17}$ acids is of the same order as that of $n$ - $\mathrm{C}_{15}$ acids. 
equally for the synthesis of 'odd'- and 'even'numbered fatty acids. In the light of the investigations of James et al. (1956) the unlabelled propionate liberated would participate in the formation of ' $n$-odd-numbered acids'. The degradation of valeric acid suggests an explanation for its absence from the blood (Annison, 1954), despite its occurrence as a normal component in the rumen.

Table 3 shows the distribution of ${ }^{14} \mathrm{C}$ among the fatty acids. On the basis of their specific activities the fatty acids may be divided into two groups. The acids of $\mathrm{C}_{4}-\mathrm{C}_{10}$ form one group with maximum specific activity at $\mathrm{C}_{4}$, which is followed by a steep decline to $\mathrm{C}_{10}$. The second group comprises the acids of $\mathrm{C}_{12}$ and above with a maximum specific activity at $\mathrm{C}_{12}$, followed by a decline with increasing molecular weight. This pattern of distribution of specific activities differs from that found by Popják, French, Hunter \& Martin (1951) in the goat-milk fat, where the specific activities rose to a maximum at $\mathrm{C}_{10}$ during the $12 \mathrm{hr}$. period after injection of labelled acetate. In the 12-48 hr. period after injection the specific activities increased from $\mathrm{C}_{4}$ to $\mathrm{C}_{16}$. This led Popják, French, Hunter \& Martin (1951) to the conclusion that all the acids up to $\mathrm{C}_{16}$ were synthesized chiefly in the udder. Shaw, Powell \& Knodt (1942) had already shown that blood fat, which consists mainly of nonvolatile fatty acids (Lough \& Garton, 1957), contributes to cow-milk fat. In the present experiment the distribution of specific activities (Table 3) is consistent with the origin of the milk fat from both sources. The specific activities appear to indicate, however, that the fatty acids $\mathrm{C}_{4}-\mathrm{C}_{10}$, rather than $\mathrm{C}_{4}-\mathrm{C}_{16}$, are predominantly synthesized in the udder, while $\mathrm{C}_{12}$ and above are synthesized at other sites, such as the liver, from separate pools containing $\left[{ }^{14} \mathrm{C}\right]$ acetate. The decline in specific activities (Table 3 ) following the maxima at $\mathrm{C}_{4}$ and $\mathrm{C}_{12}$ could be explained by the replacement of labelled by unlabelled acetate during the course of synthesis (Popják, French \& Folley, 1951; McClymont, 1949). The dilution of $\left[{ }^{14} \mathrm{C}\right]$ acetate with inactive acetate is supported by the low specific activity of the acetate isolated by us.

The $\mathrm{C}_{15}$ and $\mathrm{C}_{17}(+)$-anteiso acids, as well as the $\mathrm{C}_{12}, \mathrm{C}_{14}, \mathrm{C}_{16}$ and $\mathrm{C}_{18}$ unsaturated acids, show a lower specific activity than do the saturated straightchain acids of similar chain length. The formation of these acids from acetate therefore appears to take place at a lower rate than does that of the saturated straight-chain acids.

The specific activity of glycerol $(15.0 \mu \mathrm{c} / \mathrm{g}$. atom of carbon) was identical with that reported by M. Kleiber (personal communication, 1956). This indicates that, like propionate (Kleiber, Black, Brown \& Tolbert, 1953), a large part of the intact valerate is utilized for carbohydrate synthesis.

\section{SUMMARY}

1. The distribution of ${ }^{14} \mathrm{C}$ among fatty acids in the milk fat of a lactating cow, which had been injected with [carboxy $\left.{ }^{14} \mathrm{C}\right]$ valerate, showed that the saturated straight-chain acids of similar molecular weight, containing odd and even numbers of carbon atoms, had closely similar specific activities. Valeric acid is not, therefore, a direct precursor in the formation of saturated straight-chain acids of milk fat containing an odd number of carbon atoms. The present results are consistent with the degradation in vivo to acetate and propionate.

2. The present results suggest that the volatile fatty acids up to and including $\mathbf{C}_{\mathbf{1 0}}$ are synthesized predominantly in the udder, and that those from $\mathrm{C}_{12}$ to $\mathrm{C}_{18}$ are predominantly synthesized elsewhere.

3. The high specifie activity of glycerol carbon shows valerate to be glycogenic rather than lipogenic.

The authors are greatly indebted to Dr M. Kleiber of the University of California, Department of Animal Husbandry, Davis, U.S.A., for making available the sample of butterfat used in this investigation.

\section{REFERENCES}

Abraham, S. \& Hassid, W. Z. (1957). Methods in Enzymology, vol. 4, p. 527. Ed. by Colowick, S. P. \& Kaplan, N. O. New York: Academic Press Inc.

Annison, E. F. (1954). Biochem. J. 58, 670.

Eidinoff, M. L. (1950). Analyt. Chem. 22, 529.

Folley, S. J. (1952). Symp. biochem. Soc. 9, 52.

Glascock, R. F. (1954). Dairy Sci. Abstr. 16, 860.

Hansen, R. P., Shorland, F. B. \& Cooke, N. J. (1957). Nature, Lond., 179, 98.

Hawke, J. C. (1957). J. Dairy Res. 24, 366.

Henry, K. M. \& Kon, S. K. (1942). Biochem. J. 36, 456.

Hilditch, T. P. (1956). The Chemical Constitution of Natural Fats, 3rd ed., p. 588. London: Chapman and Hall Ltd. James, A. T. \& Martin, A. J. P. (1952). Biochem. J. 50, 679. James, A. T., Peeters, G. \& Lauryssens, M. (1956). Biochem. J. 64, 726.

Kleiber, M., Black, A. L., Brown, M. A. \& Tolbert, B. M. (1953). J. biol. Chem. 208, 339.

Lough, A. K. \& Garton, G. A. (1957). Biochem. J. 67, 345. McClymont, G. L. (1949). Biochem. J. 45, i.

Milburn, A. H.\& Truter, E. V. (1954). J. chem. Soc. p. 3344. Popják, G. (1952). Symp. biochem. Soc. 9, 37.

Popják, G., French, T. H. \& Folley, S. J. (1951). Biochem.J. 48, 411.

Popják, G., French, T. H., Hunter, G. D. \& Martin, A. J. P. (1951). Biochem. J. 48, 612.

Shaw, J. C., Powell, R. C. \& Knodt, C. B. (1942). J. Dairy Sci. 25, 909.

Shorland, F. B. (1952). J. appl. Chem. 2, 438.

Shorland, F. B., Gerson, T. \& Hansen, R. P. (1955a). Biochem. J. 61, 702.

Shorland, F. B., Gerson, T. \& Hansen, R. P. (1955b). Biochem. J. 59, 350.

Shorland, F. B. \& Hansen, R. P. (1957). Dairy Sci. Abstr. $19,168$. 